\title{
Corruption and Corporate Corruption
}

\section{* Mr. Nama Nishtha Das}

\begin{abstract}
India has one of the highest percentages of corruption. In spite of our governments various steps in its fight against this great menace, corruption continues to exist in various orgainsations - private as well as public. In this paper the various aspects of the concept of corruption with a reference of corporate corruption has been discussed.
\end{abstract}

Keyword : Corruption, Conporate Corruption, Government Subsidies

\section{Introduction}

Good Governance and Anti corruption are the two major issues that have high priority in the development process of Indian Economy. Our prime minister often talks about tamping down on corruption in India, but a recent report shows that it remains pervasive. In these days, the public awareness about the detrimental impact and severity of the problem have increased considerably The media, policy institution and non governmental organisations have raised concerns over the unprecedented level of this menace. In view of the mounting evidences and increased awareness, the government is struggling to tackle the issue through various actions and measures.

India has one of the highest percentages of corruption. In India, corruption is prevalent nor only in various sectors such a public services, police, public procurement, education etc., but also prevent at various levels of our organisations. Regarding corporate corruptions also India has one of the highest percentage, fraud particularly corruption and bribery has been the common form of corporate corruption in India. At global level 25 percent of respondents from India said that they had come across different types of fraud, which included corruption, bribery and stealing of proprietary information among other things. In comparison, only

* ISKON, Mangalore, Alumnus of B. Tech, IIT, Kanpur, 
around 18 percent of Chinese executives, 20 percent of Russian executives said that they had encountered such types of fraud.

\section{Meaning and Types}

Corruption, derived from the latin word, 'corruptus', literally means to destroy. The act of corrupting or making putrid, or state of being corrupt or putrid; decomposition or disorganization, in the process of putrefaction, deterioration. Or in other words, it is the act of changing, or of being changed, for the worse; departure from what is pure, simple, or correct; as, a corruption of style; corruption in language.

It means impairment of integrity virtue or moral principles. It could also mean using public or government property for personal greed or needs.

The types of Corruption are as follows

1) Political Corruption

2) Data Corruption

3) Police Corruption

4) Educational Corruption

5) Corporate Corruption

\section{Political Corruption}

It is the malfunctioning of a political system or institution in which politically elected officials seek illegitimate personal gain through actions such as bribery, extortion cronyism, nepotism, patronage, graft, and embezzlement. Many famous cases are in front of us for example P. M. of Israel, Natvar Singh etc.

\section{Data Corruption}

Data Corruption means copying data and publishing it on internet or in books without author permission. Now a days Privacy is one of the most talked about. Free distribution is one of the solution to it but company needs money for its operation and so free is not method in this corporate world. 


\section{Police Corruption}

Police officers accepting bribes in exchange for not reporting organized drug or prostitution rings or other illegal activities. Another example is police officers ignoring the police code of conduct in order to be fully able to catch suspects (for example using forged evidence). Another, very rare, example would be police and other government entities deliberately and systematically participating in organized crime themselves.

\section{Educational Corruption}

This form of corruption includes -

- Leakage of question paper

- Bribing the examiner

- High donation for merit seats.

- Producing fake or false certificate

- Changing caste certificate for reservation.

\section{Corporate Corruption}

There as been much discussion of corruption in the corporate sector of many developing countries. It was inevitable corruption of public servants that, in part, made it important to privatize in developing countries. Advocates of privatization also lauded the private sector's ability to compete. As these private sector advocates quite had in mind the abilities that American corporate capitalism has demonstrated recently.

They put to shame those petty government bureaucrats who stole a few thousand dollars or even a few million. The numbers bandied about in the Enron, WorldCom and other scandals are in the billions, greater than the GNP of many countries.

\section{Reasons for Corruption}

High standard of living : Natural human tendency to desire more than that can be afforded and try to satisfy these carving by illegal means.

Low salary : Some people working in government sector have low salaries and hence they resort to various illegal means for quick 
money.

Bad Government System : The vigilence system of the government is inefficient so people holding officers of power easily abuse their positions.

Addiction: Crave for more money to satisfy their urge for intoxication. Consequently they get into the trap of the corruption world which provides them with handsome full of money to quench their thirst for gambling and intoxication.

Dowry : Prominent in Rural India and to some extent in civilized urban areas. The bride's family is forced to pay large amount of money and also jewels. This forces many people to resort to corruption in form of accepting bribes etc.

Inflation : Corporate staff may involve in corruptions to meet the increasing prices due to inflation prevailing in the country.

Greed : Some people are greedy, by birth. No amount of wealth satisfies them. Greed for money, jewellery property etc forces them to indulge in corruption.

\section{Case Studies}

\section{Stamp Paper Scam}

Telgi got the idea of printing fake stamp papers and selling them to public. These denominations range from Rs. 10 to Rs. 1,000 . The quality of fake stamps coming into the market was as good as the originals and the people were easily fooled.

Over 1.200 hours of his phone conversations secretly taped by the Karnataka police while he was in jail. The former Mumbai Police Commissioner RS Sharma was the highest-ranking police officer accused in the Rs. 3,000 crore scam.

A Samajwadi Janta party legislator, Anil Gote, was arrested in connection with the case. C. Krishna Yadav, an MLA of the ruling Telgu Desam partly was arrested on grounds on demanding bribe from Telgi

Out of the 50 accused in the case, 37 were policemen.

\section{S. K. Dubey Murder Case}


Satuemdra Dubey, an IITian worked at the Ministry of Surface Transport in Delhi Indian Engineering Service (IES). India's top engineering bureaucracy, In July 2002 he was employed by the National Highway Authority of India (NHAI). Dubey became the Assistant Project Manager at Koderma, Jharkhand, responsible for managing a part of Aurangabad-Barachatti section of National Highway (The Grand Trunk Road)

Dubey discovered that the contracted firm, Larsen and Turbro, had been quietly subcontracting the actual work to smaller lowtechnology groups, controlled by the local mafia. At Gaya, he exposed large-scale flouting of NHAI rules regarding subcontracting and quality control.

Despite a request to the authorities that his identity be kept secret as its sensitive content that pointed fingers at some of his superiors, the letter along with bio-data was forwarded immediately to the Ministry for Road Transport. He was murdered. He lost his life due to corruption....

\section{ENRON}

Enron Creditors Recovery Corporation (formerly Enron Corporation, former NYSE tricker symbol ENE)_was an American energy company based in Houston, Texas. Before bankruptcy in late 2001, Enron employed approximately 22,000[1] and was one of the world's leady electricity natural gas, pulp and paper, and communication companies, with claimed revenues of nearly $\$ 101$ billion in 2000[2] Fortune named Enron "America's Most Innovative Company" for six consecutive years. At the end of 2001 it was revealed that its reported financial condition was sustained substantially by institionalized systematic, and creatively planned accounting fraud, known as the "Enron sandal." Enron has since become a popular symbol of wilful corporate fraud and corruption. The scandal was also considered a landmark case in the field of business fraud and brought into question the accounting practices of many corporations throughout the United States.

Enron field for bankruptcy protection in the Southern District of New 
York in late 2001 and selected Weil. Gotshal \& Manages as its bankruptcy counsel. It emerged from bankruptcy in November 2004 after one of the biggest and most complex bankruptcy cases in U. S history. On September 7, 2006. Enron sold Prisma Energy International Ltd. Following the scandal, lawsuits against Enron's directors were notable because the directos settled the suits by paying very significant sums of money personally. The scandal also caused the dissolution of the Arthur Andersen accounting firm, affecting the wider business world [3]

\section{Marion's Scandal}

Marion Jones was apprehended in a dope scandal.

- Resulted in a six month imprisonment

- Stripped off five Olympic medals

- Forced to retire from athletics

Right to Information Act - Law enacted by the Parliament of India giving citizens of India access to records of the Central Government and State Governments.

Under the provisions of the Act, any citizen may request information from a "public authority" which is required to reply within thirty days.

Every public authority to computerise their records for wide dissemination and to proactively publish certain categories of information. Law passed by Parliament - 15 June 2005. Came into force-13 October 2005.

\section{Solutions}

- Strict punishment for those found guilty of corruption

- Cultivating an attitude of simple living and high thinking. Mostly corrupt people are already having salary so they should learn to live within the means honestly. Real happiness and unless people are exposed to the culture of spiritual life they will be mad after material pursuits and for this end they will be corrupt to any level

- Anxiety caused by corrupt practices will not only killl our 
mental health but also spiritual well being. With a disturbed mind we cannot concentrate on anything. Fear of being caught and the news of that becoming known to all our well wishers will not allow us to sit peaceful for a minute.

- It is difficult to digest corrupt money. This easy money kills in the children spirit to work hard. Often this money leads to vices.

- Very good systems designed by govt so that corruption is minimized. Private institutions do not allow their employees to loot them. So why govt cannot have similar good systems in place.

In addition to the above, the following remedial measures also go a long way in reducing, if not preventing, corruption, corporate corruption.

\section{Paying civil servants well}

If public sector wages are too low, employees may find themselves under pressure to supplement their incomes in unofficial ways. So, pay the civil servants well.

\section{Transparency in Government Schemes}

Creating transparency and openness in govt. spending subsidies, tax exception, public procurement of goods and services, soft credit, extra budgetary funds under the control of politicians - all are elements of various ways of managing public resources by the government. Government collects tax, tap the capital market receives foreign aid, to allocate these resources to satisfy a multiplicity of needs. The more open and transparent the process means less opportunity for corruption and bribe

\section{Cutting the red tape}

There is high correlation between incidence of corruption and the extent of bureaucratic red tapism. There is a need to eliminate many needless regulations, Laws and Programmes that breed corruption while safeguarding the essential regulatory functions of the state.

4 Replacing by regressive and distorting subsidies with targeted cash transfers. 
Subsides are another example of how government policy, can distort incentives and create opportunities for corruption. There is a need to replace expensive regressive subsides with targeted cash transfers.

\section{Deploying smart technology}

The frequent direct contact between government officials and citizens can open the way for corruption, bribery and these illicit transitions. One way to reduce this problem is to use readily available technologies like internet and online platforms and keep an arms length relationship between officials and civil society.

\section{Conclusion}

There is an urgent need to combat corruption, which is prevailing in almost all organizations at various levels. In addition to the above measures implementation of citizen charter with accountability and time bound actions by the government will limit corruption to a great extent. Limiting powers of the elected politicians in terms of bribing voters through ill conceived social scheme such as MNREG and unnecessary subsidies will also be of effective measure to combat corruption. More than anything the people of the country need to develop a sense of moral character starting with individual, family and society as a whole. 